\title{
THE CONNECTION BETWEEN LOGIC AND LAW: AN INTERVIEW WITH PROFESSOR ELENA LISANYUK ${ }^{1}$
}

\author{
Interview conducted by Natalina Stamile ${ }^{2}$
}

This interview was conducted during the 5th International Legal Philosophy Symposium - Research network Brazil, Russia, Argentina and Italy - on the $25^{\text {th }}$ and $26^{\text {th }}$ of May, 2017, hosted by the Postgraduate Program in Law at the Federal University of Paraná, Brazil. The main topic of the event was "Conceptions of the Legal System" 3.

\section{Q: First of all, thank you so much, Professor Lisanyuk, for accepting this invitation. Could you start, please, by giving a brief introduction?}

A: I am Elena Lisanyuk, an Associate Professor (Docent) in the Department of Logic at St. Petersburg State University. My research degree is Dr. Hab. in Philosophical Logic. In Russia, there are two research degrees obtained by dissertation defense: The Candidate and the Doctor of Science. In addition, there are two teaching degrees, Docent and Professor, which are also the names of the corresponding university teaching \& research positions. The teaching degrees are connected to the research degrees and to the university positions, but there is no direct parallelism among the three.

I was born in Vilnius (Lithuania) to a Russian-Ukrainian family, and left Vilnius for St Petersburg (then Leningrad) for my university studies. After graduating, I stayed for my PhD and started as an assistant professor at the Department of Logic in 1997. My husband is Russian, and we have two daughters.

\section{Q: Why did you choose to study logic? Who are the authors or the logicians who most influenced you and your work?}

A: Math and Logic were my favorite subjects when I started as an undergraduate student of philosophy in St Petersburg (then Leningrad) State University. Another, and perhaps more important, reason became clear later. I found myself to be more of an analytic philosopher than a continental one; however, in Russia, it was (and still is) far more popular to study continental philosophy, so there were not many options to choose from, though logic was one of them.

Aristotle has influenced — and still influences - my studies in many ways. At different points in my career, medieval logicians William Ockham and Jean Buridan, as well as George von Wright, Johan van Benthem, Jaakko Hintikka, H. L. A. Hart and Eugenio Bulygin were the sources of guidance and inspiration for me. I would like to mention here my teacher at the Department of Logic, Professor Yaroslav Slinin, with whom I started my course thesis several decades ago; I benefited so much from our collaborations over the years. Now he is my most respected colleague.

\footnotetext{
${ }^{1}$ For Professor Lisanyuk’s CV, see: https://goo.gl/HWCHGy; Google Scholar profile: https://goo.gl/kTfjaJ; Academic blog: https://goo.gl/M214AN.

2 Ph.D in Legal Theory and European Legal Order, Magna Graecia University, Catanzaro, Italy; post-doctorate in the Postgraduate Program in Law at the Federal University of Paraná, Brazil; visiting professor of Philosophy and Legal Informatics at the University of Bergamo, Italy.

3 The author would like to thank the Academic Publishing Advisory Center (Centro de Assesoria de Publicação Acadêmica, CAPA - www.capa.ufpr.br) of the Federal University of Paraná (UFPR) for assistance with English language editing. The author gives special thanks to Daniel Persia, Fulbright English Teaching Assistant at UFPR, for guidance during the editing process at CAPA.
} 


\section{Q: Could you talk about what it is like to be a logician today, especially in Russia? Has it changed at all, over the years? If so, how?}

A: Being a logician or a philosopher in Russia is not so different from being one in Brazil, Italy or any other country. Generally, the everyday life of a university professor in Russia differs more from the life of a Russian farmer or a Russian engineer than from that of a philosopher in Brazil or in Italy. However, what is interesting about logic and logicians in Russia is that we still have two nearly parallel traditions in the development of logic, and this parallelism starts in the $17^{\text {th }}$ century, if not earlier. The first is formal logic proper and mathematical (symbolic) logic, which is, in its contemporary state, understood primarily through computability theory. Today this tradition is developed largely by Russian mathematicians and computer scientists. Initially it stemmed from the Aristotelian legacy which arrived in medieval Russia through the Latin West. A notable member of this first tradition is Platon Poretsky, a $19^{\text {th }}$ century Russian astronomer and mathematician at Kazan University. Poretsky began lecturing on mathematical logic in 1886 and published several papers in the field around that time- - the first papers in Russian in what today we call Symbolic logic. The other tradition came from Byzantium through Greek texts. It is closer to what we call today Philosophical logic, embracing both issues in the logical semantic and the remarkable diversity of modal logic. A well-known member of this second tradition is Nicolai Vasilyev, a Russian philosopher and logician and a forerunner of paraconsistent logic. Most members of the Department of Logic, including myself, belong to the second tradition.

\section{Q: Can you tell us more about your theory of logic? Do you have a specific or related legal theory? Do you believe that there is a relationship between Law and Logic? Why or why not?}

A: Since I am not a legal theorist, I have no legal theory, but as a logician, I do have a logicalcognitive theory of argumentation which I develop in my recent papers and in my book, Argumentation and Conviction (2015) ${ }^{4}$. I believe these new findings can also contribute to legal argumentation and the formal modeling of legal issues. While logical theories tell us how to handle what we consider to be true knowledge as expressed in some propositions, argumentation theories suggest how to justify our conclusions in a dispute or how to convince others that certain pieces of reasoning can or should be accepted. Logic cares about the formal correctness of its proofs and places the greatest value on deductive validity. Argumentation values arguments strong enough to confront and rebut critique. My theory proposes a family of formalisms for modeling how arguments can be defended against counterarguments in the dispute. The theory suggests special algorithms for identifying and calculating dispute solutions, if they exist. It also includes a special formalism for argumentation over actions which allows for modelling legal argumentation, as well.

Although both law and logic (as well as argumentation theories) study human rational behavior, they approach it from different angles. Although both law and logic (as well as argumentation theories) study human rational behavior, they approach it from different angles. While logic often considers its contributions to law as methodological — which legal theorists seldom dispute-law also makes a similar contribution to logic (for example, when neural nets are used to create valid reasoning patterns on the basis of valid legal decisions). However, this is not the full extent of collaboration between the two fields.

\footnotetext{
${ }^{4}$ Cf.: E. LISANYUK, АРГУМЕНТАЦИЯ И УБЕЖДЕНИЕ (Argumentation and Conviction), Nauka Publ. House, St Petersburg, 2015.
} 
Q: Today, Russia seems to be rediscovering its ancient role in many different fields. What is the current situation in regard to human rights, fundamental rights, and, in particular, religious freedom in Russia? Do you think the door has been opened for further discussion, research and advancement in these areas? Can you indicate one important decision made recently by the Russian Constitutional Court?

A: Contemporary Russia is hardly a leader in what concerns human rights, unfortunately. In some periods of its history, Russia was doing better than it is today, or at least there was hope that it would improve in the future. For example, with the legal reforms launched by tsar Alexander II in 1864, Russia obtained a judicial system, quite up-to-date for that time, which included independent juries available to most Russian people and accessible for many kinds of cases, both civil and criminal. Things started to change with the February 1917 Bourgeois and the October 1917 Bolshevik Revolutions, which had been triggered by World War I and, in many Russian cities, by women street protests against war, low incomes and rising food prices. After the 1917 Revolutions, women in Russia obtained equal labor rights with men, and they also received special social privileges related to maternity and the family. Many social services were introduced to respond to women and family needs, such as state-financed childcare, healthcare, a gender-neutral pension system and compulsory education in schools. However, contemporary statistics show that women are still paid 25\% less than men-a kind of 'penalty for motherhood.' Moreover, salaries of women with young children are 4$7 \%$ lower than those of women with grown-up children or no children at all. These differentialscombined with another 10-15\% 'social fine' for unpaid family services (child and elderly care, cleaning the house, shopping, managing the household, etc.) - not only place Russian women at a lower starting position than men, in terms of income and career, but also align closely with women's socially approved roles of mother and wife. Good examples are two recent, widely discussed cases considered by the Constitutional Court of Russia. One is the case of Constantin Markin ${ }^{5}$, a military officer who received parental leave from military service only after taking his argument to courtsomething Russian women obtain easily upon request. Another example is the case of Alyona Lymar $^{6}$, a Russian woman accused of murder who was initially denied a trial by jury. The problem here was that, in the contemporary Russian legal system, juries considered only hard criminal casesnamely, those in which the accused could be sentenced for life (it is the most serious punishment now, as the capital punishment has been under moratorium since 1997). But women cannot be sentenced for life irrespective of their crimes, according to Russian law. Whereas Lymar needed to take her argument to court to earn a trial by jury, an accused man in her situation would have automatically been granted this right. These two cases demonstrate the contemporary controversies around human rights in Russia.

\section{Q: Do you have any recommendations for students or researchers who are at the beginning of their studies in logic?}

A: I would suggest two things: (1) the textbook Language, Proof and Logic, by Jon Barwise \& John Etchemendy, which includes a very good tutorial (available both on- and offline) and a built-in

\footnotetext{
${ }^{5}$ Case of Konstantin Markin (2012) Case of Konstantin Markin v. Russia (Application no. 30078/06) Judgment. Strasbourg. 22 March 2012; https://goo.gl/GaojgX, [19.11.15]. [Дело «Константин Маркин против России» (2010) «Дело «Константин Маркин против России» (жалоба №30078/06). Постановление. Г. Страсбург, 7 октября 2010 г.», Права человека. Практика Европейского Суда по правам человека 12: 32-44; https:/goo.gl/gM5RHL.

${ }^{6}$ The Statement of the Constitutional Court of Russia \#6-П 25.02.2016 (in Russian): https://goo.gl/Z9n8Bn.
} 
grading service to verify your solutions, and (2) as more general advice, don't be afraid of formalisms; they enable us to analytically judge humans, their conduct and their motives for it, be those rational and emotional.

Q: What fundamental texts would you recommend? Do you think Literature can play a role in law? How about film? What film might you suggest for a student new to the field?

A: Regarding philosophical books, my favorites are Aristotle, John Searle and Umberto Eco. In terms of contemporary philosophers, I would highlight Eugenio Bulygin, Luciano Floridi and Timothy Williamson.

Fiction. My favorite authors are: Julio Cortázar (Rayuela shaped my early years and contributed to my habit of drinking mate tea) and E.M. Remark, Thomas Mann, John Steinbeck, F. Scott Fitzgerald, Leo Tolstoy, Fyodor Dostoevsky, Anton Chekhov - those classical authors who are always up-todate. I'm also fond of contemporary authors, especially those nominated for literary awards.

Films. For young law students, I would suggest 12 Angry Men. Try to see all of its versionsincluding the national ones made in other countries, too, not just the US Hollywood production. Generally, one can have a very good cultural experience by watching national movies. This way of "cultural travelling” gives us a sense of just how remarkably diverse our views can be on universal issues.

Thank you very much for talking with me. I look forward to meeting with you again soon! 